\title{
Oral Health and Risk of Arthritis in the Scottish Population: Results from the Scottish Health Survey
}

\author{
Hadeel Mohammed Abbood ${ }^{1}$, George Cherukara ${ }^{1}$, Ejaz Pathan ${ }^{2}$, Tatiana V. Macfarlane ${ }^{3,4}$ \\ ${ }^{1}$ Dental School and Hospital, University of Aberdeen, Aberdeen, United Kingdom. \\ ${ }^{2}$ Aberdeen Royal Infirmary, Aberdeen, United Kingdom. \\ ${ }^{3}$ Epidemiology Group, School of Medicine, Medical Sciences and Nutrition, University of Aberdeen, Aberdeen, \\ United Kingdom. \\ ${ }^{4}$ Medicines Monitoring Unit (MEMO), School of Medicine, University of Dundee, Dundee, United Kingdom.
}

\author{
Corresponding Author: \\ Hadeel Mohammed Abbood \\ University of Aberdeen Dental School \\ Cornhill Road, Foresterhill, AB25 2ZR, Aberdeen \\ United Kingdom \\ Phone: 0044 (0) 1224551585 \\ E-mail: $\underline{\text { hadeel.abbood@abdn.ac.uk }}$
}

\begin{abstract}
Objectives: To investigate the link between self-reported oral health and arthritis in the Scottish population using data from the Scottish Health Survey.

Material and Methods: Data were available from 2008 to 2013 on self-reported arthritis, oral health conditions and oral hygiene habits from the Scottish Health Survey. Arthritis was defined in this survey by self-reported long standing illness, those who reported having arthritis, rheumatism and/or fibrositis. Oral conditions were defined by self-reported bleeding gums, toothache, biting difficulties and/or edentulousness. Oral hygiene habits were defined by self-reported brushing teeth and/or using dental floss on daily basis. Logistic regression was used for statistical analysis adjusted for age, gender, qualification, smoking and body mass index.

Results: Prevalence of self-reported arthritis was 9.3\% (95\% confidence interval $[\mathrm{CI}]=9.03$ to 9.57$)$. Those who reported having bleeding gums (adjusted odds ratio $[\mathrm{OR}]=1.63 ; 95 \% \mathrm{CI}=1.35$ to 1.96$)$, toothache $(\mathrm{OR}=1.32 ; 95 \% \mathrm{CI}=1.16$ to $1.5)$, biting difficulties ( $\mathrm{OR}=1.95 ; 95 \% \mathrm{CI}=1.62$ to 2.34$)$, and being edentulous $(\mathrm{OR}=1.22 ; 95 \% \mathrm{CI}=1.08$ to 1.37$)$ had an increased risk of arthritis. Brushing teeth $(\mathrm{OR}=1.25 ; 95 \% \mathrm{CI}=0.74$ to 2.12$)$, and using dental floss $(\mathrm{OR}=1.11 ; 95 \% \mathrm{CI}=$ 0.89 to 1.39 ) were not associated with arthritis.

Conclusions: Self-reported oral conditions were associated with increased risk of self-reported arthritis. Oral hygiene habits were not associated with self-reported arthritis. Further investigation is required to assess the causal association between oral hygiene, oral disease and arthritis.
\end{abstract}

Keywords: arthritis; oral health; oral hygiene; periodontal diseases.

Accepted for publication: 29 June 2017

To cite this article:

Abbood HM, Cherukara G, Pathan E, Macfarlane TV.

Oral Health and Risk of Arthritis in the Scottish Population: Results from the Scottish Health Survey

J Oral Maxillofac Res 2017;8(2):e2

URL: http://www.ejomr.org/JOMR/archives/2017/2/e2/v8n2e2.pdf

doi: $10.5037 /$ jomr.2017.8202 


\section{INTRODUCTION}

Oral health can be defined as being free from chronic pain, tissue lesion, disease or disorder in the oral, dental and craniofacial tissues [1]. Oral diseases constitute an important public health problem due to their relatively high prevalence, impact on the individuals and society, and the cost involved in treatment [2]. The most prevalent oral diseases globally are dental caries and periodontitis []․ Toothache, biting difficulties, bleeding gums, and loss of natural teeth could all be shared manifestations and markers of both of these diseases [3-5]. Oral diseases, particularly periodontitis, have been suggested to be associated with arthritis [6-9].

Musculoskeletal diseases include a wide range of disorders affecting joints and surrounding structures [10]. They are one of the common causes of physical disability, due to their high prevalence in elderly people across the world [11]. Rheumatoid arthritis (RA) and Osteoarthritis (OA) are among the most common types of musculoskeletal diseases with different aetiology. RA which is an inflammatory autoimmune disease affects approximately $1 \%$ of the United Kingdom (UK) adult population [12]. Around $9.6 \%$ of men and $18 \%$ of women aged $\geq 60$ years have symptomatic OA which is of degenerative aetiology [13]. The term "arthritis" is a general term people use to describe OA, RA and all other forms of joint diseases [14].

Generally, the gold standard for diagnosis of both arthritis and oral diseases is clinical diagnosis. However, in large epidemiological studies, clinical diagnosis is not feasible, and is expensive. Therefore, self-reported disease questionnaires have been used in epidemiological studies. They show good agreement with medical records for acute life threatening conditions, as well as chronic conditions, such as stroke, hypertension, and diabetes [15]. For reporting arthritis as a general term, self-report showed a good agreement to physician diagnosis [16-18] Moreover, the agreement was higher in reporting a group of specific clinical diagnosis such as RA and ankylosing spondylitis [16]. Self-reported oral health questionnaire can accurately identify patients suffering from oral diseases when compared to clinical examination. Hence, it can be used to measure oral health in large epidemiological studies [19-23]. Self-reported bleeding gums have been shown to be able to correctly predict individuals with periodontal disease, due to its high specificity [23].

It has been suggested that oral disease might be a causative agent and/or risk factor for a wide range of systemic diseases [24-26]. In particular, the association between periodontitis and cardiovascular diseases [26] and diabetes [24] has been established. Similarly, an association between periodontitis and musculoskeletal conditions has been suggested [6-9]. However, evidence is still weak to claim the type of this association or its direction due to the quality of the studies conducted.

The purpose of this study is to explore the association between self-reported arthritis and oral health in the Scottish population.

\section{MATERIAL AND METHODS Study design and participants}

The Scottish Health Survey (SHeS) is a crosssectional survey that was first conducted in 1995 , and then repeated in the years 1998, 2003, and 2008. From 2008 onwards, the survey is conducted annually (http://www.gov.scot/Topics/Statistics/Browse/Health/ scottish-health-survey). This survey is not intended to identify individual's specific conditions. It describes the general behavioural, biological, and social characteristics for the population living in Scottish households. SHeS aims to develop new policies and health initiatives across the whole of Scotland. The main sample of this survey includes participants of all ages, whose addresses were drawn from both the Postcode Address File and the Scottish Government. Generally, the survey includes interview with questionnaire filling, then a follow-up nurse visit for interview questions and biological sample collection [27-32]. Data from these surveys are stored in the UK Data Archive (http://www.data-archive.ac.uk/).

For the present analysis, we combined the annual surveys from 2008 to 2013, due to the consistency in the questionnaires used during these years [27-32]. We included adult participants aged 16 years and over. Arthritis was defined by self-reporting. Those who reported long standing illness and mentioned at least one of the musculoskeletal conditions (i.e. Arthritis as result of broken limb, arthritis/rheumatism in any part of the body, gout, osteoarthritis, rheumatoid arthritis, polymyalgia rheumatic, polyarteritis nodosa, psoriasis arthritis, rheumatic symptoms, Still's disease) were defined as having self-reported arthritis. These were the only terms that were used in the SHeS to identify musculoskeletal conditions. We are aware that these conditions are general terms and cannot precisely identify the type of musculoskeletal disease that the participant has.

Oral disease status was identified by self-reporting the following questions: 
- Do your gums bleed when you eat, brush your teeth or floss?

- Have you had any toothache or pain in your mouth within the last month, or are you having any at present?

- Do you have any problems or difficulties biting or chewing food?

- How many natural teeth, including crowns have you got?

Oral hygiene practice was defined according to whether one used toothbrush with fluoridated toothpaste and/or used dental floss on daily basis. There was no data on the frequency of using toothbrush or dental floss. Oral hygiene questionnaire was only used in SHeS years 2009 [28], 2011 [30] and 2013 [32]. Table 1 represent the list of SHeS questions used in this study.

\section{Statistical analysis}

Descriptive statistics were used for univariate analyses. Total number and percentages were calculated for each variable. Chi-square $\left(\chi^{2}\right)$ test was used for comparison between proportions. Logistic regression was used to calculate odds ratio (OR) and 95\% confidence interval (CI) to describe the association between self-reported arthritis and oral disease, and self-reported arthritis and oral hygiene practice. Adjustments were made for potential confounding factors, including age, gender, qualification, smoking and body mass index (BMI). Statistical significance level was defined at $P=0.05$. All data were processed by IBM SPSS statistics Software package, version 24.

\section{RESULTS}

The total number of participants included in the SHeS 2008 to 2013 [27-32] was 46038. Over half of the participants were women $(n=25964$ [56.4\%]). The mean age of participants was 50.8 (standard deviation [SD] 18.2) years. The response rate ranged from $54-56 \%$, with a higher response rate in women (57-60\%) than men (50-52\%) [33-38].

Table 1. Questions from Scottish Health Survey used in this study

\begin{tabular}{|c|c|c|}
\hline & Type of question & Notes \\
\hline \multirow{4}{*}{$\begin{array}{l}\text { Questions on } \\
\text { oral health } \\
\text { conditions }\end{array}$} & $\begin{array}{l}\text { Do your gums bleed when you eat, } \\
\text { brush your teeth or floss? }\end{array}$ & $\begin{array}{l}\text { Answers showed in card as: } \\
\text { 1. Yes often; } \\
\text { 2. Yes, occasionally; } \\
\text { 3. No, never. } \\
\text { The interviewer coded the answer (Dichotomised during analysis as Yes/No). }\end{array}$ \\
\hline & $\begin{array}{l}\text { Have you had any toothache or pain } \\
\text { in your mouth within the last month, } \\
\text { or are you having any at present? }\end{array}$ & $\begin{array}{l}\text { Answers showed in card as Yes/No. } \\
\text { The interviewer coded the answer. }\end{array}$ \\
\hline & $\begin{array}{l}\text { Do you have any problems or } \\
\text { difficulties biting or chewing food? }\end{array}$ & $\begin{array}{l}\text { Answers showed in card as: } \\
\text { 1. Yes often; } \\
\text { 2. Yes, occasionally; } \\
\text { 3. No, never. } \\
\text { The interviewer coded the answer (Dichotomised during analysis as Yes/No). }\end{array}$ \\
\hline & $\begin{array}{l}\text { Adults can have up to } 32 \text { natural } \\
\text { teeth but over time people lose some } \\
\text { of them. How many natural teeth, } \\
\text { including crowns have you got? }\end{array}$ & $\begin{array}{l}\text { Answers showed in card as: } \\
\text { 1. No natural teeth; } \\
\text { 2. Fewer than } 10 \text { natural teeth; } \\
\text { 3. Between } 10 \text { and } 19 \text { natural teeth; } \\
\text { 4. } 20 \text { or more natural teeth. } \\
\text { The interviewer coded the answer. }\end{array}$ \\
\hline $\begin{array}{l}\text { Question on } \\
\text { oral hygiene } \\
\text { habits }\end{array}$ & $\begin{array}{l}\text { Which of the following do you do } \\
\text { daily to improve your dental and oral } \\
\text { health }\end{array}$ & $\begin{array}{l}\text { Answers showed in cards including: } \\
\text { 1. Brushing my teeth with fluoridated toothpaste; } \\
\text { 2. Use dental floss; } \\
\text { The interviewer coded all that apply. }\end{array}$ \\
\hline $\begin{array}{l}\text { Question on } \\
\text { arthritis }\end{array}$ & $\begin{array}{l}\text { Do you have a long-standing } \\
\text { physical or mental condition or } \\
\text { disability that has troubled you for at } \\
\text { least } 12 \text { months, or that is likely to } \\
\text { affect you for at least } 12 \text { months? }\end{array}$ & $\begin{array}{l}\text { Answered by Yes/No. } \\
\text { If yes, the answer is recorded by the interviewer and any of the below } \\
\text { mentioned terms will be recorded under the code "Arthritis/rheumatism/ } \\
\text { fibrositis". } \\
\text { The terms are: "Arthritis as result of broken limb, arthritis/rheumatism in } \\
\text { any part of the body, gout, osteoarthritis, rheumatoid arthritis, polymyalgia } \\
\text { rheumatic, polyarteritis nodosa, psoriasis arthritis, rheumatic symptoms, } \\
\text { Still's disease". }\end{array}$ \\
\hline
\end{tabular}




\section{Prevalence of self-reported arthritis}

The overall prevalence of self-reported arthritis was $9.3 \%$ (95\% CI $=9.03$ to 9.57). It increased with age. The highest prevalence was in those aged more than 75 years $\left(21 \%\right.$; $\chi^{2}$ test, $\left.\mathrm{P}<0.001\right)$ (Table 2$)$. The prevalence was higher in women compared to men $\left(10.8 \%\right.$ vs. $7.4 \%$; $\chi^{2}$ test, $\left.\mathrm{P}<0.001\right)$. Participants with no educational qualification reported the highest level of arthritis (17.8\%). The prevalence decreased with increasing level of educational qualification $\left(\chi^{2}\right.$ test, $\left.\mathrm{P}<0.001\right)$. The prevalence of arthritis was the lowest in underweight $(4.9 \%)$ and the highest in obese participants $\left(12.8 \% ; \chi^{2}\right.$ test, $\left.\mathrm{P}<0.001\right)$. It was lower in participants who had never smoked $(7.8 \%)$

Table 2. Prevalence of self-reported arthritis by sociodemographic factors in Scottish population according to the Scottish Health Surveys 2008 - 2013 [27-32]

\begin{tabular}{|c|c|c|c|}
\hline \multicolumn{2}{|r|}{ Factor } & $\begin{array}{c}\text { Total } \\
\mathbf{N}\end{array}$ & $\begin{array}{c}\text { Self-reported } \\
\text { arthritis, N (\%) }\end{array}$ \\
\hline \multicolumn{2}{|l|}{ Overall } & 46038 & $4298(9.3)$ \\
\hline \multirow{7}{*}{ Age } & $<25$ & 4578 & $18(0.4)$ \\
\hline & $26-35$ & 6083 & $59(1)$ \\
\hline & $36-45$ & 7907 & $249(3.2)$ \\
\hline & $46-55$ & 8393 & $578(6.9)$ \\
\hline & $56-65$ & 7994 & $1229(15.4)$ \\
\hline & $66-75$ & 6527 & $1210(18.5)$ \\
\hline & $>75$ & 4556 & $955(21)$ \\
\hline & & \multicolumn{2}{|c|}{$\chi^{2}$ test $\mathrm{P}$-value $<0.001$} \\
\hline \multicolumn{4}{|l|}{ Gender } \\
\hline \multicolumn{2}{|l|}{ Male } & 20074 & $1486(7.4)$ \\
\hline \multirow{2}{*}{\multicolumn{2}{|c|}{ Female }} & 25964 & $2812(10.8)$ \\
\hline & & \multicolumn{2}{|c|}{$\chi^{2}$ test $P$-value $<0.001$} \\
\hline \multicolumn{4}{|c|}{ Qualification } \\
\hline \multicolumn{2}{|c|}{ No qualifications } & 10401 & $1848(17.8)$ \\
\hline \multicolumn{2}{|c|}{$\mathrm{HNC} / \mathrm{D}$ or equivalent or lower } & 23491 & $1736(7.4)$ \\
\hline \multirow{2}{*}{\multicolumn{2}{|c|}{ Ordinary degree or higher }} & 11957 & $698(5.8)$ \\
\hline & & \multicolumn{2}{|c|}{$\chi^{2}$ test $\mathrm{P}$-value $<0.001$} \\
\hline \multicolumn{4}{|c|}{ Body mass index } \\
\hline \multicolumn{2}{|c|}{ Underweight $(<18.5)$} & 550 & $27(4.9)$ \\
\hline \multicolumn{2}{|c|}{ Normal weight (18.5 - 25) } & 11892 & $609(5.1)$ \\
\hline \multicolumn{2}{|c|}{ Overweight $(25-30)$} & 14400 & $1161(8.1)$ \\
\hline \multirow{2}{*}{\multicolumn{2}{|c|}{ Obese $(>30)$}} & 11374 & $1450(12.8)$ \\
\hline & & \multicolumn{2}{|c|}{$\chi^{2}$ test $\mathrm{P}$-value $<0.001$} \\
\hline \multicolumn{4}{|c|}{ Smoking status } \\
\hline \multicolumn{2}{|l|}{ Never } & 21194 & $1661(7.8)$ \\
\hline \multicolumn{2}{|c|}{ Ex-smoker } & 13761 & $1680(12.2)$ \\
\hline \multirow{2}{*}{\multicolumn{2}{|c|}{ Current }} & 10856 & $951(8.8)$ \\
\hline & & \multicolumn{2}{|c|}{$\chi^{2}$ test $\mathrm{P}$-value $<0.001$} \\
\hline
\end{tabular}

$\mathrm{N}=$ number of cases; $\chi^{2}=$ Chi-square. than both current smokers $(8.8 \%)$ and previous smokers $\left(12.2 \%\right.$; $\chi^{2}$ test, $\left.\mathrm{P}<0.001\right)($ Table 2$)$.

\section{Prevalence of self-reported oral diseases}

The overall prevalence of bleeding gums, toothache and biting difficulties was $5.2 \%, 13.5 \%$ and $3.6 \%$, respectively. The prevalence of bleeding gums and toothache tended to decrease with age $\left(\chi^{2}\right.$ test, $\mathrm{P}<0.001$ for both), whereas the prevalence of biting difficulties increased with age ( $\chi^{2}$ test, $\left.\mathrm{P}<0.001\right)$. The prevalence of bleeding gums was higher in women than men $\left(5.5 \%\right.$ vs. $4.9 \%$; $\chi^{2}$ test, $\left.\mathrm{P}=0.011\right)$ as well as toothache $\left(14 \%\right.$ vs. $12.9 \% ; \chi^{2}$ test, $\left.\mathrm{P}=0.002\right)$. However, no statistically significant difference was observed between women and men in reporting biting difficulties $\left(3.7 \%\right.$ vs. $3.6 \% ; \chi^{2}$ test, $\left.\mathrm{P}=0.63\right)$ (Table 3). The prevalence of both bleeding gums and biting difficulties declined with increasing level of education. In contrast, the prevalence of toothache was lower in participants with no educational qualification than other participants $\left(\chi^{2}\right.$ test, $\left.\mathrm{P}=0.003\right)$ (Table 3 ).

Overall, the prevalence of edentulism was $13.4 \%$. Edentulism increased with age, reaching to its highest level in the oldest age group (49.2\%). The prevalence of loss of natural teeth among women was $14.3 \%$ versus $12.2 \%$ among men $\left(\chi^{2}\right.$ test, $\left.\mathrm{P}<0.001\right)$. About a third of those with no qualification were edentulous $\left(33.2 \%\right.$; $\chi^{2}$ test, $\left.\mathrm{P}<0.001\right)$ (Table 3 ).

The prevalence of bleeding gums increased with increasing number of natural teeth. Those who reported having bleeding gums were $5.3 \%$ of those who had 20 or more natural teeth, and $3.9 \%$ of those who had fewer than 10 natural teeth $\left(\chi^{2}\right.$ test, $\mathrm{P}=0.004)$. There was no change in the prevalence of toothache with increasing number of natural teeth. The prevalence of toothache in those who have 20 or more natural teeth was $13.6 \%, 13.3 \%$ in those who had 19 to 10 natural teeth, and $13 \%$ in those who had fewer than 10 natural teeth $\left(\chi^{2}\right.$ test, $\mathrm{P}=0.62)$. Prevalence of biting difficulties decreased with increasing number of natural teeth. Only $2.3 \%$ of those who had 20 or more natural teeth reported having biting difficulties compared to $11.1 \%$ of those who had fewer than 10 natural teeth $\left(\chi^{2}\right.$ test, $\mathrm{P}<0.001)$ (Table 4).

\section{Prevalence of self-reported oral hygiene behaviour}

The oral hygiene questionnaire was only used in the years 2009 [28], 2011 [30] and 2013 [르] (Table 5). Overall, the questionnaire was answered by 9891 participants, $86.1 \%$ of whom reported using toothbrush regularly with fluoridated toothpaste. 
Table 3. Prevalence of measurement of oral health problems in Scottish population according the Scottish Health Surveys 2008 - 2013 [27-32]

\begin{tabular}{|c|c|c|c|c|c|}
\hline Factor & $\begin{array}{c}\text { Total } \\
\mathbf{N}\end{array}$ & $\begin{array}{l}\text { Bleeding gums } \\
\quad \mathbf{N}(\%)\end{array}$ & $\begin{array}{l}\text { Toothache } \\
\text { N (\%) }\end{array}$ & $\begin{array}{c}\text { Biting difficulties } \\
\text { N (\%) }\end{array}$ & $\begin{array}{c}\text { Edentulism } \\
\text { N (\%) }\end{array}$ \\
\hline Overall & 46038 & $2073(5.2)$ & $5370(13.5)$ & $1446(3.6)$ & $6160(13.4)$ \\
\hline \multicolumn{6}{|l|}{ Age } \\
\hline$<25$ & 4578 & $296(6.5)$ & 898 (19.7) & $116(2.5)$ & $7(0.2)$ \\
\hline $26-35$ & 6083 & $444(7.4)$ & $988(16.4)$ & $193(3.2)$ & $34(0.6)$ \\
\hline $36-45$ & 7907 & $507(6.5)$ & $1072(13.8)$ & $263(3.4)$ & $138(1.7)$ \\
\hline $46-55$ & 8393 & $430(5.4)$ & $1095(13.8)$ & 334 (4.2) & $450(5.4)$ \\
\hline $56-65$ & 7994 & $262(3.9)$ & $717(10.7)$ & $256(3.8)$ & $1297(16.3)$ \\
\hline $66-75$ & 6527 & $108(2.4)$ & $408(9)$ & $182(4)$ & $2001(30.7)$ \\
\hline$>75$ & 4556 & $26(1.1)$ & $192(8.3)$ & $102(4.4)$ & $2233(49.2)$ \\
\hline$\chi^{2}$ test $P$-value & & $<0.001$ & $<0.001$ & $<0.001$ & $<0.001$ \\
\hline \multicolumn{6}{|l|}{ Gender } \\
\hline Male & 20074 & $860(4.9)$ & $2266(12.9)$ & $630(3.6)$ & $2450(12.2)$ \\
\hline Female & 25964 & $1213(5.5)$ & $3104(14)$ & $816(3.7)$ & $3710(14.3)$ \\
\hline$\chi^{2}$ test $\mathrm{P}$-value & & 0.011 & 0.002 & $0.63^{\mathrm{a}}$ & $<0.001$ \\
\hline \multicolumn{6}{|l|}{ Qualification } \\
\hline No qualifications & 10401 & $383(5.5)$ & $856(12.3)$ & $353(5.1)$ & 3447 (33.2) \\
\hline $\mathrm{HNC} / \mathrm{D}$ or equivalent or lower & 23491 & $1133(5.3)$ & $2956(13.9)$ & $755(3.6)$ & $2242(9.5)$ \\
\hline Ordinary degree or higher & 11957 & $556(4.8)$ & $1545(13.4)$ & $335(2.9)$ & $454(3.8)$ \\
\hline$\chi^{2}$ test $\mathrm{P}$-value & & $0.075^{\mathrm{a}}$ & 0.003 & $<0.001$ & $<0.001$ \\
\hline \multicolumn{6}{|l|}{ Body mass index } \\
\hline Underweight & 550 & $17(3.7)$ & $82(17.9)$ & $24(5.2)$ & $91(16.5)$ \\
\hline Normal weight & 11892 & $527(4.9)$ & $1563(14.6)$ & $415(3.9)$ & $1152(9.7)$ \\
\hline Overweight & 14400 & $610(4.8)$ & $1632(12.9)$ & $404(3.2)$ & $1729(12)$ \\
\hline Obese & 11374 & $630(6.4)$ & $1302(13.3)$ & $353(3.6)$ & $1589(14)$ \\
\hline$\chi^{2}$ test P-value & & $<0.001$ & $<0.001$ & 0.008 & $<0.001$ \\
\hline \multicolumn{6}{|l|}{ Smoking status } \\
\hline Never & 21194 & $896(4.6)$ & $2162(11.2)$ & $413(2.1)$ & $1843(8.7)$ \\
\hline Ex-smoker & 13761 & $620(5.5)$ & $1440(12.9)$ & 399 (3.6) & $2569(18.7)$ \\
\hline Current & 10856 & $550(6)$ & $1748(19.2)$ & $630(6.9)$ & $1747(16.1)$ \\
\hline$\chi^{2}$ test $\mathrm{P}$-value & & $<0.001$ & $<0.001$ & $<0.001$ & $<0.001$ \\
\hline
\end{tabular}

${ }^{a}$ No statistically significant at the level $\mathrm{P}<0.05$ (Chi-square test).

$\mathrm{N}=$ number of cases; $\chi^{2}=$ Chi-square

Table 4. Prevalence of oral health conditions according to the number of natural teeth

\begin{tabular}{l|c|c|c}
\hline \multirow{2}{*}{ Number of natural teeth } & \multicolumn{3}{|c}{ Prevalence of oral health conditions } \\
\cline { 2 - 4 } & $\begin{array}{c}\text { Bleeding gums } \\
\mathbf{N}(\%)\end{array}$ & $\begin{array}{c}\text { Toothache } \\
\mathbf{N}(\%)\end{array}$ & $\begin{array}{c}\text { Biting difficulties } \\
\mathbf{N}(\%)\end{array}$ \\
\hline $\begin{array}{l}\mathbf{2 0} \text { or more natural teeth } \\
(\mathrm{N}=30851)\end{array}$ & $1648(5.3)$ & $4191(13.6)$ & $715(2.3)$ \\
\hline $\begin{array}{l}\mathbf{1 9} \text { to 10 natural teeth } \\
(\mathrm{N}=6024)\end{array}$ & $312(5.2)$ & $801(13.3)$ & $406(6.7)$ \\
\hline $\begin{array}{l}\text { Fewer than 10 natural teeth } \\
(\mathrm{N}=2879)\end{array}$ & $112(3.9)$ & $375(13)$ & $321(11.1)$ \\
\hline$\chi^{2}$ test P-value & 0.004 & $0.62^{\mathrm{a}}$ & $<0.001$ \\
\hline
\end{tabular}

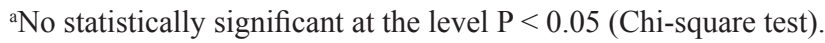

$\mathrm{N}=$ number of cases; $\chi^{2}=$ Chi-square. 
Table 5. Prevalence of oral health behaviour in Scottish population according to the Scottish Health Survey 2009 [28], 2011 [30] and 2013 [32]

\begin{tabular}{|c|c|c|c|}
\hline Factor & $\begin{array}{c}\text { Total } \\
\mathbf{N}\end{array}$ & $\begin{array}{c}\text { Brushing } \\
\text { N (\%) }\end{array}$ & $\begin{array}{c}\text { Using dental floss } \\
\mathrm{N}(\%)\end{array}$ \\
\hline Overall & 9891 & $8519(86.1)$ & $2250(22.7)$ \\
\hline \multicolumn{4}{|l|}{ Age } \\
\hline$<25$ & 977 & $936(95.8)$ & $196(20.1)$ \\
\hline $26-35$ & 1354 & $1323(97.7)$ & $329(24.3)$ \\
\hline $36-45$ & 1695 & $1628(96)$ & $481(28.4)$ \\
\hline $46-55$ & 1847 & $1707(92.4)$ & $536(29)$ \\
\hline $56-65$ & 1705 & $1435(84.2)$ & $371(21.8)$ \\
\hline $66-75$ & 1330 & $947(71.2)$ & $244(18.3)$ \\
\hline$>75$ & 983 & $543(55.2)$ & $93(9.5)$ \\
\hline$\chi^{2}$ test P-value & & $<0.001$ & $<0.001$ \\
\hline \multicolumn{4}{|l|}{ Gender } \\
\hline Male & 4335 & $3717(85.7)$ & $653(15.1)$ \\
\hline Female & 5556 & $4802(86.4)$ & $1597(28.7)$ \\
\hline$\chi^{2}$ test P-value & & $0.33^{\mathrm{a}}$ & $<0.001$ \\
\hline \multicolumn{4}{|l|}{ Qualification } \\
\hline No qualifications & 2164 & $1485(68.6)$ & $233(10.8)$ \\
\hline $\mathrm{HNC} / \mathrm{D}$ or equivalent or lower & 5088 & $4517(88.8)$ & $1178(23.2)$ \\
\hline Ordinary degree or higher & 2613 & $2502(95.8)$ & $835(32)$ \\
\hline$\chi^{2}$ test P-value & & $<0.001$ & $<0.001$ \\
\hline \multicolumn{4}{|l|}{ Body mass index } \\
\hline Underweight & 107 & $84(78.5)$ & $26(24.3)$ \\
\hline Normal weight & 2548 & $2298(90.2)$ & $688(27)$ \\
\hline Overweight & 2975 & $2622(88.1)$ & $657(22.1)$ \\
\hline Obese & 2420 & $2074(85.7)$ & $517(21.4)$ \\
\hline$\chi^{2}$ test P-value & & $<0.001$ & $<0.001$ \\
\hline \multicolumn{4}{|l|}{ Smoking status } \\
\hline Never & 4680 & 4268 (91.2) & $1206(25.8)$ \\
\hline Ex-smoker & 2859 & 2369 (82.9) & $655(22.9)$ \\
\hline Current & 2326 & $1857(79.8)$ & $383(16.5)$ \\
\hline$\chi^{2}$ test P-value & & $<0.001$ & $<0.001$ \\
\hline
\end{tabular}

${ }^{a}$ No statistically significant at the level $\mathrm{P}<0.05$ (Chi-square test).

$\mathrm{N}=$ number of cases; $\chi^{2}=$ Chi-square.

Dental floss use was reported by $22.7 \%$ of the participants. Generally, the use of toothbrush decreased with age $\left(\chi^{2}\right.$ test, $\left.\mathrm{P}<0.001\right)$. Whereas, the prevalence of regular dental floss use was the highest in the middle age groups: 46 - 55 age group $(29 \%)$ and $36-45$ age groups $\left(28.4 \% ; \chi^{2}\right.$ test, $\left.\mathrm{P}<0.001\right)$. High percentage of men $(85.7 \%)$ and women $(86.4 \%)$ reported using toothbrush $\left(\chi^{2}\right.$ test, $\left.\mathrm{P}=0.33\right)$. However, women were more likely to use dental floss than men $\left(28.7 \%\right.$ vs. $15.1 \%$; $\chi^{2}$ test, $\left.\mathrm{P}<0.001\right)$.

The prevalence of both toothbrush and dental floss use increased with increasing level of education. The prevalence was the lowest in those who had no educational qualification $(68.6 \%$ for using toothbrush and $10.8 \%$ for using dental floss), and the highest in participants who had Scottish Credit and Qualification Framework (SCQF) equal to 9 or above (i.e. ordinary degree, honours degree, master or doctorate) $(95.8 \%$ for using toothbrush and $32 \%$ for using dental floss) (Table 5).

The prevalence of practicing good oral hygiene was statistically significantly low in participants who reported having bleeding gums, toothache, and biting difficulties $\left(\chi^{2}\right.$ test, $\left.\mathrm{P}<0.001\right)$. It was statistically significantly high in patients having more than 20 natural teeth. The prevalence of practicing good oral hygiene decreased with decreasing the number of natural teeth $\left(\chi^{2}\right.$ test, $\left.\mathrm{P}<0.001\right)$ (Table 6 ). 
Table 6. Prevalence of oral hygiene practicing in participants reported suffering from oral diseases [27-32]

\begin{tabular}{|c|c|c|c|c|c|c|c|c|c|}
\hline \multirow[t]{2}{*}{ Factor } & \multicolumn{2}{|c|}{$\begin{array}{l}\text { Bleeding gums } \\
\text { N (\%) }\end{array}$} & \multicolumn{2}{|c|}{$\begin{array}{c}\text { Toothache } \\
\text { N (\%) }\end{array}$} & \multicolumn{2}{|c|}{$\begin{array}{c}\text { Biting difficulties } \\
\text { N }(\%)\end{array}$} & \multicolumn{3}{|c|}{$\begin{array}{c}\text { Number of } \\
\text { natural teeth }\end{array}$} \\
\hline & No & Yes & No & Yes & No & Yes & $>20$ & $10-19$ & $<10$ \\
\hline Toothbrush & $7811(96.5)$ & $439(92.4)$ & 7166 (96.6) & 1084 (93.9) & 7959 (96.5) & $291(90.7)$ & $6531(97.8)$ & $1174(93.5)$ & $541(85.7)$ \\
\hline$\chi^{2}$ test $\mathrm{P}$-value & \multicolumn{2}{|c|}{$<0.001$} & \multicolumn{2}{|c|}{$<0.001$} & \multicolumn{2}{|c|}{$<0.001$} & \multicolumn{2}{|c|}{$<0.001$} & \\
\hline Dental floss & $2149(26.5)$ & $97(20.4)$ & $1986(26.8)$ & $260(22.5)$ & $2190(26.5)$ & $56(17.4)$ & $1968(29.5)$ & $231(18.4)$ & $44(7)$ \\
\hline$\chi^{2}$ test P-value & \multicolumn{2}{|c|}{0.003} & \multicolumn{2}{|c|}{0.002} & \multicolumn{2}{|c|}{$<0.001$} & \multicolumn{3}{|c|}{$<0.001$} \\
\hline
\end{tabular}

$\mathrm{N}=$ number of cases; $\chi^{2}=$ Chi-square.

The relationship between self-reported arthritis, oral disease, and oral hygiene

In order to assess the relationship between selfreported arthritis and indicators of oral disease, OR and $95 \%$ CI was calculated adjusted for age, gender, educational level, smoking and BMI. There was a statistically significant association between selfreported arthritis and self-reported bleeding gums $(\mathrm{OR}=1.63 ; 95 \% \mathrm{CI}=1.35$ to 1.96$)$, toothache $(\mathrm{OR}=1.32 ; 95 \% \mathrm{CI}=1.16$ to 1.5$)$ and biting difficulties $(\mathrm{OR}=1.95 ; 95 \% \mathrm{CI}=1.62$ to 2.34$)$.
Partial or complete edentulism were also associated with increased risk of arthritis. OR $=1.29(95 \%$ $\mathrm{CI}=1.16$ to 1.44 ) for those who retained 20 to 10 of their natural teeth, $\mathrm{OR}=1.45(95 \% \mathrm{CI}=1.27$ to 1.66) for those who have less than 10 natural teeth, and $\mathrm{OR}=1.22(95 \% \mathrm{CI}=1.08$ to 1.37$)$ for complete edentulousness (Table 7).

The use of toothbrush $(\mathrm{OR}=1.25 ; 95 \% \mathrm{CI}=0.74$ to 2.12) was not associated with the risk of selfreported arthritis. Similarly, the use of dental floss was not strongly associated with self-reported arthritis $(\mathrm{OR}=1.11 ; 95 \% \mathrm{CI}=0.89$ to 1.39$)($ Table 7$)$.

Table 7. Relationship between self-reported oral health and oral health behaviour and self-reported arthritis in Scottish population according to Scottish Health Surveys [27-32]

\begin{tabular}{|c|c|c|c|c|}
\hline Factor & $\begin{array}{c}\text { Total } \\
\mathbf{N}\end{array}$ & $\begin{array}{c}\text { Self-reported arthritis } \\
\mathbf{N}(\%)\end{array}$ & OR $(95 \% \mathrm{CI})^{\mathrm{a}}$ & $\begin{array}{c}\text { OR }(95 \% \mathrm{CI})^{\mathrm{a}} \\
\text { excluding age }>65\end{array}$ \\
\hline \multicolumn{5}{|l|}{ Number of natural teeth } \\
\hline$>20$ & 30844 & $1628(5.3)$ & 1 & 1 \\
\hline $10-19$ & 6023 & $812(13.5)$ & $1.29(1.16 ; 1.44)$ & $1.37(1.19 ; 1.58)$ \\
\hline$<10$ & 2878 & $563(19.6)$ & $1.45(1.27 ; 1.66)$ & $1.53(1.26 ; 1.86)$ \\
\hline Edentulous & 6160 & $1288(20.9)$ & $1.22(1.08 ; 1.37)$ & $1.49(1.26 ; 1.76)$ \\
\hline \multicolumn{5}{|l|}{ Bleeding gums } \\
\hline No & 37687 & $2828(7.5)$ & 1 & 1 \\
\hline Yes & 2073 & $177(8.5)$ & $1.63(1.35 ; 1.96)$ & $1.48(1.19 ; 1.84)$ \\
\hline \multicolumn{5}{|l|}{ Toothache } \\
\hline No & 34395 & $2583(7.5)$ & 1 & 1 \\
\hline Yes & 5369 & $422(7.9)$ & $1.32(1.16 ; 1.5)$ & $1.34(1.15 ; 1.56)$ \\
\hline \multicolumn{5}{|l|}{ Biting difficulties } \\
\hline No & 38319 & $2786(7.3)$ & 1 & 1 \\
\hline Yes & 1445 & $219(15.2)$ & $1.95(1.62 ; 2.34)$ & $2.11(1.69 ; 2.64)$ \\
\hline \multicolumn{5}{|c|}{ Brushing teeth with fluoride toothpaste } \\
\hline No & 1372 & $304(22.2)$ & 1 & 1 \\
\hline Yes & 8519 & $663(7.8)$ & $1.25(0.74 ; 2.12)$ & $1.04(0.51 ; 2.12)$ \\
\hline \multicolumn{5}{|l|}{ Use dental floss } \\
\hline No & 7641 & $800(10.5)$ & 1 & 1 \\
\hline Yes & 2250 & $167(7.4)$ & $1.11(0.89 ; 1.39)$ & $1.03(0.78 ; 1.37)$ \\
\hline
\end{tabular}

${ }^{a}$ Odds ratio (95\% Confidence Interval) adjusted for age, gender, qualification, smoking and BMI.

$\mathrm{N}=$ number of cases. 
Further analysis by excluding participants aged more than 65 years shows minor changes in the results (Table 7); the risk of self-reported arthritis increased in edentulous participants $(\mathrm{OR}=1.49(95 \% \mathrm{CI}=1.26$ to 1.76 ). There was a minor change in the association between oral hygiene habits and the risk of selfreported arthritis, although these changes were still not significant. OR of self-reported arthritis was $1.04(95 \% \mathrm{CI}=0.51$ to 2.12$)$ for those who reported brushing their teeth on daily basis, and OR 1.03 (95\% $\mathrm{CI}=0.78$ to 1.37 ) for those who reported using dental floss on daily basis (Table 7).

\section{DISCUSSION \\ Study characteristics}

This large population-based study showed that indicators of oral disease, such as bleeding gums, toothache, biting difficulties, and tooth loss, were associated with increased risk of self-reported arthritis. However, this study cannot assess the temporality of this association.

Generally, the age and gender were evenly distributed in the study population. The descriptive statistics for the prevalence of arthritis show similar results to the prevalence of arthritis according to age and gender in UK population [12]. This supports the generalisability of the study population. The high prevalence in our study suggests the combined prevalence of both OA and RA. Smoking, low educational level, and BMI were associated with high prevalence of arthritis, which is not surprising, as smoking, low educational level and increase BMI are known risk factors for RA [39-43]. It has also been found in our study that smoking shows a highly significant association with bleeding gums, toothache, biting difficulties, and number of natural teeth (Table 3). Such strong association was also previously shown between smoking and oral health problems including periodontitis and tooth loss $[\underline{44}, \underline{45}]$.

\section{Self-reporting for diagnosis}

The SHeS was based on self-reporting arthritis in general, regardless of the type of arthritis. It seems likely that those who responded positively to the question on arthritis may suffer from any one or more of the joints diseases such as RA and OA [14]. Given that the prevalence of RA in the population is $1 \%$ [12], whereas the prevalence of arthritis reported in our study was $9 \%$, it is likely that this population represented both RA, OA, and other forms of arthritis. The authors did not have access to the participants' medical or dental records to determine specific types of arthritis or the participants' oral health status. However, self-reported arthritis, as a general term, and manifestations/markers of oral diseases are accepted for use in epidemiological studies [16-23].

\section{The relationship between self-reported bleeding gums and arthritis}

The finding of an association between bleeding gums and increased risk of arthritis was supported by several previous studies which showed an increase in bleeding on probing (during periodontal examination) in patients with RA compared to healthy controls [7-9]. These studies were based on clinical diagnosis of RA and periodontal examination of the participants. However, these studies had relatively small sample sizes ranging from 15 patients and 10 controls to 290 patients and 49 controls [7-9]. Gingival bleeding after tooth brushing, flossing or even periodontal examination is one of the signs of periodontitis [5]. The link between periodontitis and arthritis has in turn been previously established by a systematic review conducted by Kaur et al. [6]. But, the mechanism of this association needs further investigation. It could simply be due to the effect of arthritis on individuals' ability to brush/floss their teeth, and therefore lead to increased incidence of bleeding gums. Although, others hypothesised that periodontal pathogens in patients with periodontitis might translocated to the synovial joints where they might break the tolerance to citrullinated host proteins leading to RA $[\underline{46}, \underline{47}]$.

\section{The relationship between self-reported toothache, biting difficulties and arthritis}

Toothache and biting difficulties can be interrelated. They may also be manifestations of oral diseases including temporomandibular joint (TMJ) disorders. We could not identify the cause for self-reported toothache and biting difficulties from the SHeS. However, it is possible that in patients with arthritis the TMJ might be involved $[48,49]$ which might lead to biting difficulties and potentially toothache. This might be why we found an association.

To our knowledge, the relationship between toothache and self-reported arthritis has not been studied, and our study is the first to report an association between them. Toothache could also be caused as a result of dental caries, trauma, or acute periodontal infection (i.e. periodontal abscess) [4]. However, it may be premature to link lack of oral health to arthritis directly. 
The relationship between self-reported tooth loss and arthritis

Participants, who were partially or completely edentulous, were more likely to report arthritis compared to those who retained all of their natural teeth. It is reasonable to consider tooth loss as a consequence of dental disease secondary to neglecting oral hygiene. However, it is still unclear whether poor oral hygiene precedes arthritis. Conversely, as tooth loss increase with advancing age, the association might only coincidental in that with age arthritis also increases. Therefore, it may not be reasonable to suggest that oral disease as indicated by tooth loss is linked to arthritis.

\section{The relationship between self-reported oral hygiene and arthritis}

In our study, there was no association between practicing good oral hygiene on daily basis with reporting arthritis. There was no data available on the frequency of using toothbrush and dental floss. The data available only mentioned whether participants used these oral hygiene measures on daily basis or not. Good oral hygiene measures on daily basis reduce bacterial growth on teeth surfaces [50], and hence can provide good oral health. There is a growing evidence that oral bacteria might be one of the causes of arthritis [51-54]. Few studies reported the presence of chromosomal DNA from bacteria associated with periodontitis, in the synovial fluid of arthritis [5154]. These studies suggested that bacteria can be translocated from the oral cavity to the synovial fluid in patients with arthritis and suffering from periodontitis [51-54]. Such findings led to develop the hypothesis of breaking the tolerance to the citrullinated host proteins by periodontal pathogens $[\underline{46}, \underline{47}]$.

Arthritis might not affect the patient's willingness to practice good oral hygiene. However, it might affect patient's ability to use his/her hands for routine daily work [55], which may influence the effectiveness of brushing and/or flossing. Therefore, patients with arthritis may have poor oral hygiene that might lead to oral disease. Our study did not assess the effectiveness of brushing and/or flossing.

\section{Study limitations and strengths}

The main limitation of this study was the use of selfreported data. The status of arthritis, oral disease and oral hygiene practices were based on self-reporting by participants themselves. Patients may not be able to distinguish between $\mathrm{OA}$ and RA $[17,18]$, a fact which may hamper the validity of the reporting of these conditions. However, within this limitation, selfreporting has been validated and successfully used in many epidemiological studies [16-23] .

This study cannot investigate the temporal association between practicing oral hygiene and arthritis, as this study was based on a cross-sectional survey. Since cross-sectional studies lack the temporal association between exposure and disease, it may not help in identifying the cause of arthritis [ㄷ]. Therefore, a large cohort study is needed to assess the temporal association between practicing oral hygiene and arthritis in order to investigate whether poor oral hygiene precedes arthritis.

It has been shown that $\mathrm{SHeS}$ captures a representative sample of Scottish individuals living in private households [57]. However, this survey has excluded people who are residents in communal establishments, such as educational, medical, or care establishments [27-32]. These people are likely to be older and, on average, in poorer health than people residing in private households. As a result, the generalisability of the study may have been weakened. However, according to Scotland's census 2011, only $2 \%$ $(99,000 / 5,295,403$ persons) were living in communal establishments [툐].

In order to express the generalisability of the survey, the margins of error, which serves as an important tool that provide a picture of the likelihood of error that may have occurred during sampling, can be calculated. According to the number of Scottish population and the sample size of the SHeS (2008 to 2013), the margins of error would be $0.45 \%$ (https:// www.checkmarket.com/sample-size-calculator/). This means that the sample size for this study was highly representative of the Scottish population which is one of the strengths of SHeS.

Oral health can have an impact on daily life [59]. Studying oral health related quality of life (OHRQoL) helps in developing evidence based public health policies [60], assist in identifying psychosocial problems [61], and outcomes of care [62]. OHRQoL can be assessed by special questionnaires that are widely used and have an acceptable validity. Unfortunately, SHeS did not use a questionnaire to assess OHRQoL. Therefore, this study cannot investigate the effect of OHRQoL on arthritis patients. A few studies have investigated the impact of OHRQoL on arthritis patients and showed that patients with arthritis had reduced quality of life compared to healthy participants $[\underline{63}, \underline{64}]$. Further studies are recommended to investigate OHRQoL in arthritis patients. 
Within the limitations mentioned, our findings suggest an association between self-reported arthritis and oral health. This, however, requires further observational studies and prospective cohorts that are based on medical diagnosis to musculoskeletal conditions as well as oral health, in order to establish cause and effect relationship. Once this association is thoroughly established, the burden of arthritis may be reduced through maintaining good oral hygiene and managing oral diseases.

\section{CONCLUSIONS}

This study has shown that there was a statistical association between self-reported oral conditions and self-reported arthritis. Reporting regular oral hygiene practice was not associated with self-reported arthritis. There is a need for a large cohort study to identify the temporal association between practicing oral hygiene and periodontal disease, and subsequent arthritis.

\section{ACKNOWLEDGMENTS AND DISCLOSURE STATEMENTS}

We acknowledge the ScotCen Social Research, Scottish Government and the UK Data Archive for providing these data for research purposes. They bear no responsibility for any further analysis or interpretation. Hadeel Mohammed Abbood received funding from the Higher Committee for Education Development in Iraq (HCED-Iraq) to undertake her $\mathrm{PhD}$. Hadeel Mohammed Abbood is grateful to Ms Shifa Sarica (Epidemiology Group, University of Aberdeen, UK) for help with manuscript editing.

The authors declare no conflicts of interest related to this study.

Although all efforts are made to ensure the quality of the materials, neither the original data creators, depositors, the funders of neither the data collections, nor the UK Data Archive bear any responsibility for the accuracy or comprehensiveness of these materials.

\section{REFERENCES}

1. Petersen PE. The World Oral Health Report 2003: continuous improvement of oral health in the 21st century--the approach of the WHO Global Oral Health Programme. Community Dent Oral Epidemiol. 2003 Dec;31 Suppl 1:3-23. [Medline: 15015736] [doi: 10.1046/j..2003.com122.x]

2. Sheiham A. Oral health, general health and quality of life. Bull World Health Organ 2005;83(9):644-644. [Medline: 16211151] [PMC free article: 2626333]

3. Petersen PE, Bourgeois D, Ogawa H, Estupinan-Day S, Ndiaye C. The global burden of oral diseases and risks to oral health. Bull World Health Organ. 2005 Sep;83(9):661-9. [Medline: 16211157] [PMC free article: 2626328]

4. DeAngelis AF, Barrowman RA, Harrod R, Nastri AL. Review article: Maxillofacial emergencies: oral pain and odontogenic infections. Emerg Med Australas. 2014 Aug;26(4):336-42. [Medline: 25065769] [doi: 10.1111/1742-6723.12266]

5. Newbrun E. Indices to measure gingival bleeding. J Periodontol. 1996 Jun;67(6):555-61. [Medline: 8794964] [doi: 10.1902/jop.1996.67.6.555]

6. Kaur S, White S, Bartold PM. Periodontal disease and rheumatoid arthritis: a systematic review. J Dent Res. 2013 May;92(5):399-408. [Medline: 23525531] [doi: 10.1177/0022034513483142]

7. Boatca M, Hurjui L, Rudnic I, Nicolaiciuc O, Silvia Martu S. Clinical and Biological Study of rheumatoid arthritis influence on salivary biomarkers in patients with periodontal disease. Balk J Dent Med. 2015;19(3):150-2. [doi: 10.1515/bjdm-2015-0051]

8. Wolff B, Berger T, Frese C, Max R, Blank N, Lorenz HM, Wolff D. Oral status in patients with early rheumatoid arthritis: a prospective, case-control study. Rheumatology (Oxford). 2014 Mar;53(3):526-31. [Medline: 24273047] [doi: 10.1093/rheumatology/ket362]

9. Choi IA, Kim JH, Kim YM, Kim KH, Kim HW, Shin K, Lee EY, Lee EB, Lee YM, Song YW. THU0058 Periodontal disease is associated with rheumatoid arthritis (RA) but its severity is not correlated with RA disease activity. Ann Rheum Dis. 2013;71:172. [doi: 10.1136/annrheumdis-2012-eular.2023]

10. Woolf AD, Pfleger B. Burden of major musculoskeletal conditions. Bull World Health Organ. 2003;81(9):646-56. Epub 2003 Nov 14. [Medline: 14710506] [PMC free article: 2572542]

11. March L, Smith EU, Hoy DG, Cross MJ, Sanchez-Riera L, Blyth F, Buchbinder R, Vos T, Woolf AD. Burden of disability due to musculoskeletal (MSK) disorders. Best Pract Res Clin Rheumatol. 2014 Jun;28(3):353-66. [Medline: 25481420] [doi: 10.1016/j.berh.2014.08.002]

12. Symmons D, Turner G, Webb R, Asten P, Barrett E, Lunt M, Scott D, Silman A. The prevalence of rheumatoid arthritis in the United Kingdom: new estimates for a new century. Rheumatology (Oxford). 2002 Jul;41(7):793-800. [Medline: 12096230] [doi: 10.1093/rheumatology/41.7.793]

13. Murray C, Lopez A. The global burden of disease. A comprehensive assessment of mortality and disability from diseases, injuries, and risk factors in 1990 and projected to 2020. Boston: Harvard School of Public Health on behalf of the World Health Organization and The World Bank; 1996. [URL: http://www.who.int/iris/handle/10665/41842] 
14. Lawrence RC, Helmick CG, Arnett FC, Deyo RA, Felson DT, Giannini EH, Heyse SP, Hirsch R, Hochberg MC, Hunder GG, Liang MH, Pillemer SR, Steen VD, Wolfe F. Estimates of the prevalence of arthritis and selected musculoskeletal disorders in the United States. Arthritis Rheum. 1998 May;41(5):778-99. [Medline: 9588729] [doi: 10.1002/1529-0131(199805)41:53.0.CO;2-V]

15. Okura Y, Urban LH, Mahoney DW, Jacobsen SJ, Rodeheffer RJ. Agreement between self-report questionnaires and medical record data was substantial for diabetes, hypertension, myocardial infarction and stroke but not for heart failure. J Clin Epidemiol. 2004 Oct;57(10):1096-103. [Medline: 15528061] [doi: 10.1016/j.jclinepi.2004.04.005]

16. Rasooly I, Papageorgiou AC, Badley EM. Comparison of clinical and self reported diagnosis for rheumatology outpatients. Ann Rheum Dis. 1995 Oct;54(10):850-2. [Medline: 7492227] [PMC free article: 1010023] [doi: 10.1136/ard.54.10.850]

17. Bombard JM, Powell KE, Martin LM, Helmick CG, Wilson WH. Validity and reliability of self-reported arthritis: Georgia senior centers, 2000-2001. Am J Prev Med. 2005 Apr;28(3):251-8. [Medline: 15766612] [doi: 10.1016/j.amepre.2004.12.004]

18. Peeters GM,Alshurafa M, Schaap L, de Vet HC. Diagnostic accuracy of self-reported arthritis in the general adult population is acceptable. J Clin Epidemiol. 2015 Apr;68(4):452-9. [Medline: 25459981] [doi: 10.1016/i.jclinepi.2014.09.019]

19. Heloë LA. Comparison of dental health data obtained from questionnaires, interviews and clinical examination. Scand J Dent Res. 1972;80(6):495-9. [Medline: 4575038] [doi: 10.1111/j.1600-0722.1972.tb00318.x]

20. Palmqvist S, Söderfeldt B, Arnbjerg D. Self-assessment of dental conditions: validity of a questionnaire. Community Dent Oral Epidemiol. 1991 Oct;19(5):249-51. [Medline: 1742986] [doi: 10.1111/j.1600-0528.1991.tb00160.x]

21. Gilbert GH, Duncan RP, Kulley AM. Validity of self-reported tooth counts during a telephone screening interview. J Public Health Dent. 1997 Summer;57(3):176-80. [Medline: 9383757] [doi: 10.1111/j.1752-7325.1997.tb02970.x]

22. Pitiphat W, Garcia RI, Douglass CW, Joshipura KJ. Validation of self-reported oral health measures. J Public Health Dent. 2002 Spring;62(2):122-8. [Medline: 11989207] [doi: 10.1111/j.1752-7325.2002.tb03432.x]

23. Abbood HM, Hinz J, Cherukara G, Macfarlane TV. Validity of Self-Reported Periodontal Disease: A Systematic Review and Meta-Analysis. J Periodontol. 2016 Dec;87(12):1474-1483. [Medline: 27523519] [doi: 10.1902/jop.2016.160196]

24. Casanova L, Hughes FJ, Preshaw PM. Diabetes and periodontal disease: a two-way relationship. Br Dent J. 2014 Oct;217(8):433-7. [Medline: 25342350] [doi: 10.1038/sj.bdj.2014.907]

25. Scannapieco FA, Bush RB, Paju S. Periodontal disease as a risk factor for adverse pregnancy outcomes. A systematic review. Ann Periodontol. 2003 Dec;8(1):70-8. [Medline: 14971249] [doi: 10.1902/annals.2003.8.1.70]

26. Yu YH, Chasman DI, Buring JE, Rose L, Ridker PM. Cardiovascular risks associated with incident and prevalent periodontal disease. J Clin Periodontol. 2015 Jan;42(1):21-8. [Medline: 25385537] [PMC free article: 4300240] [doi: 10.1111/jepe.12335]

27. Scottish Centre for Social Research, University College London. Department of Epidemiology and Public Health. Scottish Health Survey, 2008. [data collection]. 3rd Edition. UK Data Service; 2016. SN: 6383. [doi: 10.5255/UKDA-SN-6383-3]

28. Scottish Centre for Social Research, University College London, Department of Epidemiology and Public Health,Scottish Health Survey, 2009. [data collection]. 5th Edition. 2016.

29. ScotCen Social Research, University College London. Department of Epidemiology and Public Health. Scottish Health Survey, 2010. [data collection]. 2nd Edition. UK Data Service; 2016. SN: 6987. [doi: 10.5255/UKDA-SN-6987-2]

30. ScotCen Social Research, University College London. Department of Epidemiology and Public Health, University of Glasgow. MRC/CSO Social and Public Health Sciences Unit. Scottish Health Survey, 2011. [data collection]. 4th Edition. UK Data Service; 2016. SN: 7247. [doi: 10.5255/UKDA-SN-7247-4]

31. ScotCen Social Research, University College London. Department of Epidemiology and Public Health, University of Glasgow. MRC/CSO Social and Public Health Sciences Unit. Scottish Health Survey, 2012. [data collection]. 3rd Edition. UK Data Service; 2015. SN: 7417. [doi: 10.5255/UKDA-SN-7417-3]

32. ScotCen Social Research. Scottish Health Survey, 2013. [data collection]. 2nd Edition. UK Data Service; 2015. SN: 7594. [doi: 10.5255/UKDA-SN-7594-2]

33. Corbett J, Gray L, Leyland A, MacGregor A, Marryat L, Bromley C, Bradshaw P, Given L. The Scottish health Survey 2008. Volume 2: Technical report. The Scottish Government, Edinburgh; 2009. [URL: http://www.gov.scot]

34. Corbett J, Dobbie F, Doig M, D’Souza J, Gray L, Leyland A, MacGregor A, Marryat L, Maw T, Miller M, Mindell J, Ormston R, Roth M, Sharp C, Bromley C, Given L, Ormston R. The Scottish Health Survey 2009. Volume 2 : Technical report. The Scottish Government, Edinburgh; 2010. [URL: http://www.gov.scot]

35. Bromley C, Given L, Corbett J, Day J, Doig M, Gharib W, Gray L, Leyland A, MacGregor A, Marryat L, Maw T, McConnville S, McManus S, Mindell J, Pickering K, Roth M, Sharp C. The Scottish Health Survey 2010. Volume 2: Technical report. The Scottish Government, Edinburgh; 2011. [URL: http://www.gov.scot]

36. Rutherford L, Sharp C, Bromley C, Bradshaw P, Corbett J, Day J, Doig M, Dowling S, Gharib W, Gray L, Hill T, Leyland A, McManus S, Mindell J, Pickering K, Reid S, Roth M, Whalley R. The Scottish Health Survey 2011. Volume 3: Technical report. The Scottish Government, Edinburgh; 2012. [URL: http://www.gov.scot]

37. Corbett J, Day J, Davidson M, Doig M, Dowling S, Gharib W, Hampson A, Roth M, Rutherford L, Hinchliffe S, Sharp C. The Scottish Health Survey 2012. Volume 2: Technical report. The Scottish Government, Edinburgh; 2013. [URL: http://www.gov.scot] 
38. Corbett J, Day J, Doig M, Dowling S, Martin S, Stannard A, Rutherford L, Hinchliffe S, Sharp C. The Scottish Health Survey 2013. Volume 2: Technical report. The Scottish Government, Edinburgh; 2014. [URL: http://www.gov.scot]

39. Silman AJ, Newman J, MacGregor AJ. Cigarette smoking increases the risk of rheumatoid arthritis. Results from a nationwide study of disease-discordant twins. Arthritis Rheum. 1996 May;39(5):732-5. [Medline: 8639169] [doi: 10.1002/art.1780390504]

40. Klareskog L, Malmström V, Lundberg K, Padyukov L, Alfredsson L. Smoking, citrullination and genetic variability in the immunopathogenesis of rheumatoid arthritis. Semin Immunol. 2011 Apr;23(2):92-8. [Medline: 21376627] [doi: 10.1016/j.smim.2011.01.014]

41. Millar K, Lloyd SM, McLean JS, Batty GD, Burns H, Cavanagh J, Deans KA, Ford I, McConnachie A, McGinty A, Mõttus R, Packard CJ, Sattar N, Shiels PG, Velupillai YN, Tannahill C. Personality, socio-economic status and inflammation: cross-sectional, population-based study. PLoS One. 2013;8(3):e58256. [Medline: 23516457] [PMC free article: 3596406 ] [doi: 10.1371/journal.pone.0058256]

42. Callahan LF, Pincus T. Education, self-care, and outcomes of rheumatic diseases: further challenges to the "biomedical model" paradigm. Arthritis Care Res. 1997 Oct;10(5):283-8. [Medline: 9362594] [doi: 10.1002/art.1790100502]

43. Daïen CI, Sellam J. Obesity and inflammatory arthritis: impact on occurrence, disease characteristics and therapeutic response. RMD Open. 2015 Jun 29;1(1):e000012. [Medline: 26509048] [PMC free article: 4613154] [doi: 10.1136/rmdopen-2014-000012]

44. Hanioka T, Ojima M, Tanaka K, Matsuo K, Sato F, Tanaka H. Causal assessment of smoking and tooth loss: a systematic review of observational studies. BMC Public Health. 2011 Apr 8;11:221. [Medline: 21477320] [PMC free article: 3087682 ] [doi: 10.1186/1471-2458-11-221]

45. Laxman VK, Annaji S. Tobacco use and its effects on the periodontium and periodontal therapy. J Contemp Dent Pract. 2008 Nov 1;9(7):97-107. [Medline: 18997922]

46. Wegner N, Lundberg K, Kinloch A, Fisher B, Malmström V, Feldmann M, Venables PJ. Autoimmunity to specific citrullinated proteins gives the first clues to the etiology of rheumatoid arthritis. Immunol Rev. 2010 Jan;233(1):34-54. [Medline: 20192991] [doi: 10.1111/j.0105-2896.2009.00850.x]

47. Quirke AM, Lugli EB, Wegner N, Hamilton BC, Charles P, Chowdhury M, Ytterberg AJ, Zubarev RA, Potempa J, Culshaw S, Guo Y, Fisher BA, Thiele G, Mikuls TR, Venables PJ. Heightened immune response to autocitrullinated Porphyromonas gingivalis peptidylarginine deiminase: a potential mechanism for breaching immunologic tolerance in rheumatoid arthritis. Ann Rheum Dis. 2014 Jan;73(1):263-9. [Medline: 23463691] [PMC free article: 3888615] [doi: 10.1136/annrheumdis-2012-202726]

48. Bruce B, Martin G. Temporomandibular disorders. Burket's Textbook of Oral Medicine: Diagnosis and Treatment Canada: Elsevier; 2008. p. 271-306

49. Crowson CS, Matteson EL, Myasoedova E, Michet CJ, Ernste FC, Warrington KJ, Davis JM 3rd, Hunder GG, Therneau TM, Gabriel SE. The lifetime risk of adult-onset rheumatoid arthritis and other inflammatory autoimmune rheumatic diseases. Arthritis Rheum. 2011 Mar;63(3):633-9. [Medline: 21360492] [PMC free article: 3078757] [doi: 10.1002/art.30155]

50. Löe H. Oral hygiene in the prevention of caries and periodontal disease. Int Dent J. 2000 Jun;50(3):129-39. [Medline: 10967765] [doi: 10.1111/j.1875-595X.2000.tb00553.x]

51. Martinez-Martinez RE, Abud-Mendoza C, Patiño-Marin N, Rizo-Rodríguez JC, Little JW, Loyola-Rodríguez JP. Detection of periodontal bacterial DNA in serum and synovial fluid in refractory rheumatoid arthritis patients. J Clin Periodontol. 2009 Dec;36(12):1004-10. [Medline: 19929953] [doi: 10.1111/j.1600-051X.2009.01496.x]

52. Mikuls TR, Payne JB, Reinhardt RA, Thiele GM, Maziarz E, Cannella AC, Holers VM, Kuhn KA, O’Dell JR. Antibody responses to Porphyromonas gingivalis (P.gingivalis) in subjects with rheumatoid arthritis and periodontitis. Int Immunopharmacol. 2009 Jan;9(1):38-42. [Medline: 18848647] [PMC free article: 2748386] [doi: 10.1016/j.intimp.2008.09.008]

53. Reichert S, Haffner M, Keyßer G, Schäfer C, Stein JM, Schaller HG, Wienke A, Strauss H, Heide S, Schulz S. Detection of oral bacterial DNA in synovial fluid. J Clin Periodontol. 2013 Jun;40(6):591-8. [Medline: 23534379] [doi: $10.1111 /$ jepe.12102]

54. Témoin S, Chakaki A, Askari A, El-Halaby A, Fitzgerald S, Marcus RE, Han YW, Bissada NF. Identification of oral bacterial DNA in synovial fluid of patients with arthritis with native and failed prosthetic joints. J Clin Rheumatol. 2012 Apr;18(3):117-21. [Medline: 22426587] [PMC free article: 3888235] [doi: 10.1097/RHU.0b013e3182500c95]

55. Batchelor P. The changing epidemiology of oral diseases in the elderly, their growing importance for care and how they can be managed. Age Ageing. 2015 Nov;44(6):1064-70. [Medline: 26504122] [doi: 10.1093/ageing/afv148]

56. Sedgwick P. Cross sectional studies: advantages and disadvantages. BMJ 2014;348:g2276. [doi: 10.1136/bmj.g2276]

57. Gray L, Batty GD, Craig P, Stewart C, Whyte B, Finlayson A, Leyland AH. Cohort profile: the Scottish health surveys cohort: linkage of study participants to routinely collected records for mortality, hospital discharge, cancer and offspring birth characteristics in three nationwide studies. Int J Epidemiol. 2010 Mar 25;39(2):345-50. [doi: 10.1093/ije/dyp155]

58. National Records of Scotland. Scotland's census 2011. [URL: http://www.scotlandscensus.gov.uk/census-results]. 
59. Locker D, Allen F. What do measures of 'oral health-related quality of life' measure? Community Dent Oral Epidemiol. 2007 Dec;35(6):401-11. [Medline: 18039281] [doi: 10.1111/j.1600-0528.2007.00418.x]

60. Guyatt GH, Feeny DH, Patrick DL. Measuring health-related quality of life. Ann Intern Med. 1993 Apr 15;118(8):622-9. [Medline: 8452328] [doi: 10.7326/0003-4819-118-8-199304150-00009]

61. Fitzpatrick R, Fletcher A, Gore S, Jones D, Spiegelhalter D, Cox D. Quality of life measures in health care. I: Applications and issues in assessment. BMJ. 1992 Oct 31;305(6861):1074-7. [Medline: 1467690] [PMC free article: 1883623] [doi: $10.1136 / \mathrm{bmj} .305 .6861 .1074$ ]

62. Fayers PM, Machin D. Quality of life: assessment, analysis and interpretation. London: John Wiley \& Sons; 2002. p. 85-7. [doi: $10.1002 / 0470846283]$

63. Ahola K, Saarinen A, Kuuliala A, Leirisalo-Repo M, Murtomaa H, Meurman JH. Impact of rheumatic diseases on oral health and quality of life. Oral Dis. 2015 Apr;21(3):342-8. [Medline: 25158802] [doi: 10.1111/odi.12285]

64. Blaizot A, Monsarrat P, Constantin A, Vergnes JN, de Grado GF, Nabet C, Cantagrel A, Sixou M. Oral health-related quality of life among outpatients with rheumatoid arthritis. Int Dent J. 2013 Jun;63(3):145-53. [Medline: 23691959] [doi: 10.1111/idj.12023]

\section{To cite this article:}

Abbood HM, Cherukara G, Pathan E, Macfarlane TV.

Oral Health and Risk of Arthritis in the Scottish Population: Results from the Scottish Health Survey

J Oral Maxillofac Res 2017;8(2):e2

URL: http://www.ejomr.org/JOMR/archives/2017/2/e2/v8n2e2.pdf

doi: $10.5037 /$ jomr.2017.8202

Copyright (C) Abbood HM, Cherukara G, Pathan E, Macfarlane TV. Published in the JOURNAL OF ORAL \& MAXILLOFACIAL RESEARCH (http://www.ejomr.org), 30 June 2017.

This is an open-access article, first published in the JOURNAL OF ORAL \& MAXILLOFACIAL RESEARCH, distributed under the terms of the Creative Commons Attribution-Noncommercial-No Derivative Works 3.0 Unported License, which permits unrestricted non-commercial use, distribution, and reproduction in any medium, provided the original work and is properly cited. The copyright, license information and link to the original publication on (http://www.ejomr.org) must be included. 